OPEN ACCESS

Citation: Yeng W.S., Boyce P.C. (2020) Studies on the Dipterocarpaceae of Borneo, II. Ant stipule-brood sites and extra floral nectary association in saplings of Shorea macrophylla [sect. Pachycarpae] in Sarawak, Malaysian Borneo. Webbia. Journal of Plant Taxonomy and Geography 75(1): 29-34. doi: $10.36253 / j o p t-8183$

Received: February 26, 2020

Accepted: April 27, 2020

Published: June 30, 2020

Copyright: ( 2020 Yeng W.S., Boyce P.C.. This is an open access, peerreviewed article published by Firenze University Press (http://www.fupress. com/webbia) and distributed under the terms of the Creative Commons Attribution License, which permits unrestricted use, distribution, and reproduction in any medium, provided the original author and source are credited.

Data Availability Statement: All relevant data are within the paper and its Supporting Information files.

Competing Interests: The Author(s) declare(s) no conflict of interest.

Funding: This study is funded by the Ministry of Higher Education, Malaysia through Vote No. FRGS/ ST03(03)/1300/2015(17).

Editor: Riccardo M. Baldini, University of Florence, Italy

\section{Studies on the Dipterocarpaceae of Borneo, II. Ant stipule-brood sites and extra floral nectary association in saplings of Shorea macrophylla [sect. Pachycarpae] in Sarawak, Malaysian Borneo}

\author{
Wong Sin Yeng ${ }^{1,2,3, *}$, Peter C. Boyce 3 \\ ${ }^{1}$ Institute of Biodiversity and Environmental Conservation, Universiti Malaysia Sarawak \\ 94300 Kota Samarahan, Sarawak, Malaysia \\ ${ }^{2}$ Harvard University Herbaria, 22 Divinity Avenue, Cambridge, MA 02138, U.S.A. \\ ${ }^{3}$ Ludwig-Maximilians-Universität München, Department Biologie I, Systematische \\ Botanik und Mykologie, Menzinger Straße 67, 80638 München, Germany \\ ${ }^{\star}$ Corresponding author. e-mail: sywong@unimas.my
}

\begin{abstract}
The presence of stipular and leaf blade extra floral nectaries and associated ant activity, including brood raising within stipules, is reported for saplings of Shorea macrophylla [sect. Pachycarpae] in Kuching Division, Sarawak.
\end{abstract}

Keywords: Dipterocarpaceae, Shorea Section Pachycarpae, Rubroshorea, Borneo, Sarawak, ants.

\section{INTRODUCTION}

The intricate and mutually beneficial associations existing between ants and tropical forest plants were first described for Asia by Beccari (18841886) and elaborated upon by Van Leeuwen (1913, 1923a,b,c). Subsequently an extensive body of literature has been generated for tropical Asia, notably for Euphorbiaceae (Macaranga - see for example Fiala et al. 1991), Rubiaceae (Huxley 1978; Razafimandimbison et al. 2005; Jebb \& Huxley 2019), Melastomataceae (Clausing 1997), Apocynaceae (Kleijn and van Donkelaar 2001; Peeters \& Wiwatwitaya 2014; Weissflog et al. 2017), and for the palm genus Korthalsia (Chan et al. 2012; Miler et al. 2016). Good general overviews for one lowland area of Peninsular Malaysia are provided of Fiala and Saw (2003) and Moog et al. 2003.

The Dipterocarpaceae, the dominant family of the canopy layer of lowland and hill forest in tropical Asia has no published reports of ant association on Borneo, despite the fact that the understory saplings of several species are routinely found with accompanying ants, especially at the active 


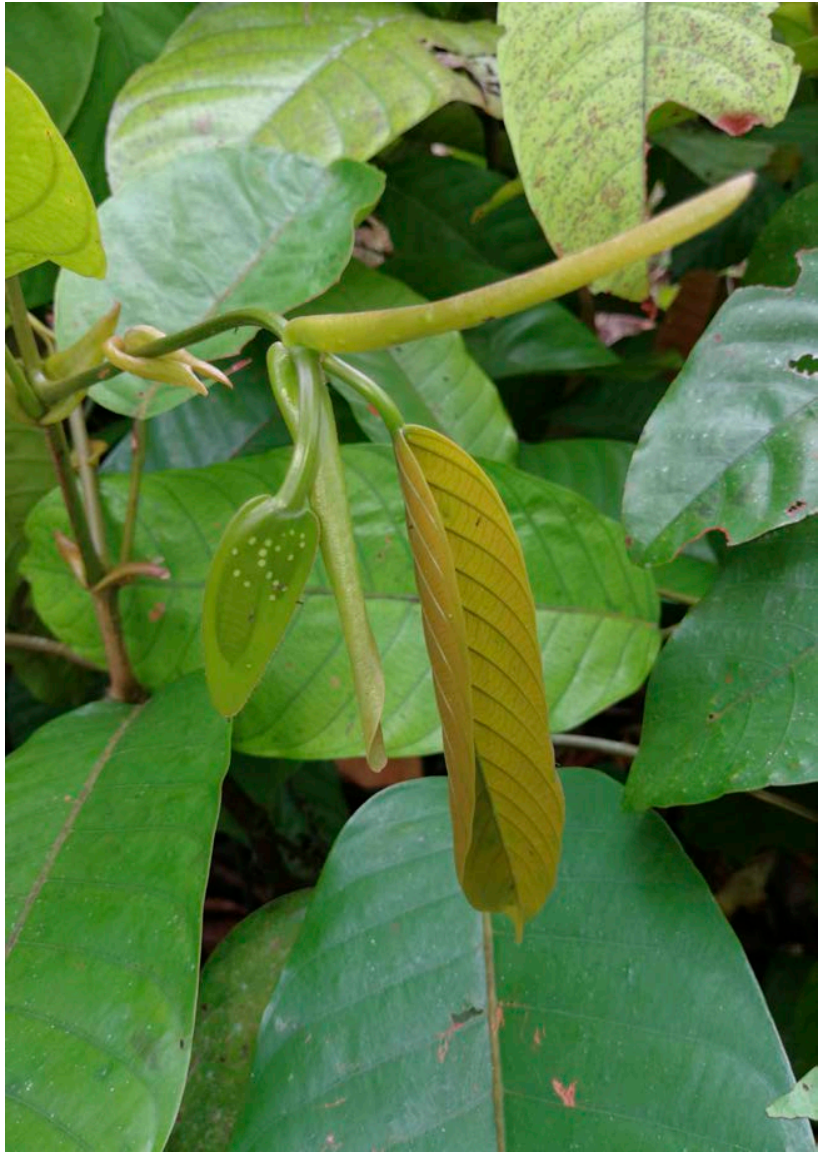

Figure 1. Shorea macrophylla Active shoot tip of sapling. Note the long revolute stipules and the pale elliptical extrafloral nectaries on the newest stipules.

shoot tips. Here we report ant association and stipule nesting in Shorea macrophylla (de Vriese) P.S.Ashton [section Pachycarpae sensu Ashton 1963, 1982; Rubroshorea gen. nov. ined. sensu Maury 1978, 1979; MauryLechon 1979a,b, Maury-Lechon and Curtet 1998; see also Heckenhauer et al. 2017, 2018, 2019)]. To the best of our knowledge these are the first in situ observations for this species, although an image of extrafloral nectaries on the stipules of $S$. macrophylla, not native there but planted in the Forest Research Institute Malaysia, appears in Fiala and Saw (2003: Fig. 3).

Shorea macrophylla is a characteristic species of the forested flood plains a west Borneo, frequently developing almost pure stands and immediately recognizable by innovations with the long somewhat briefly persistent stipules (Figure $1 \& 2$ ). Saplings and young trees have disproportionately long wide-spreading plagiotropic branches typical of sect. Pacycarpae, with leaves of these branches distichously arranged and attached directly to the stem
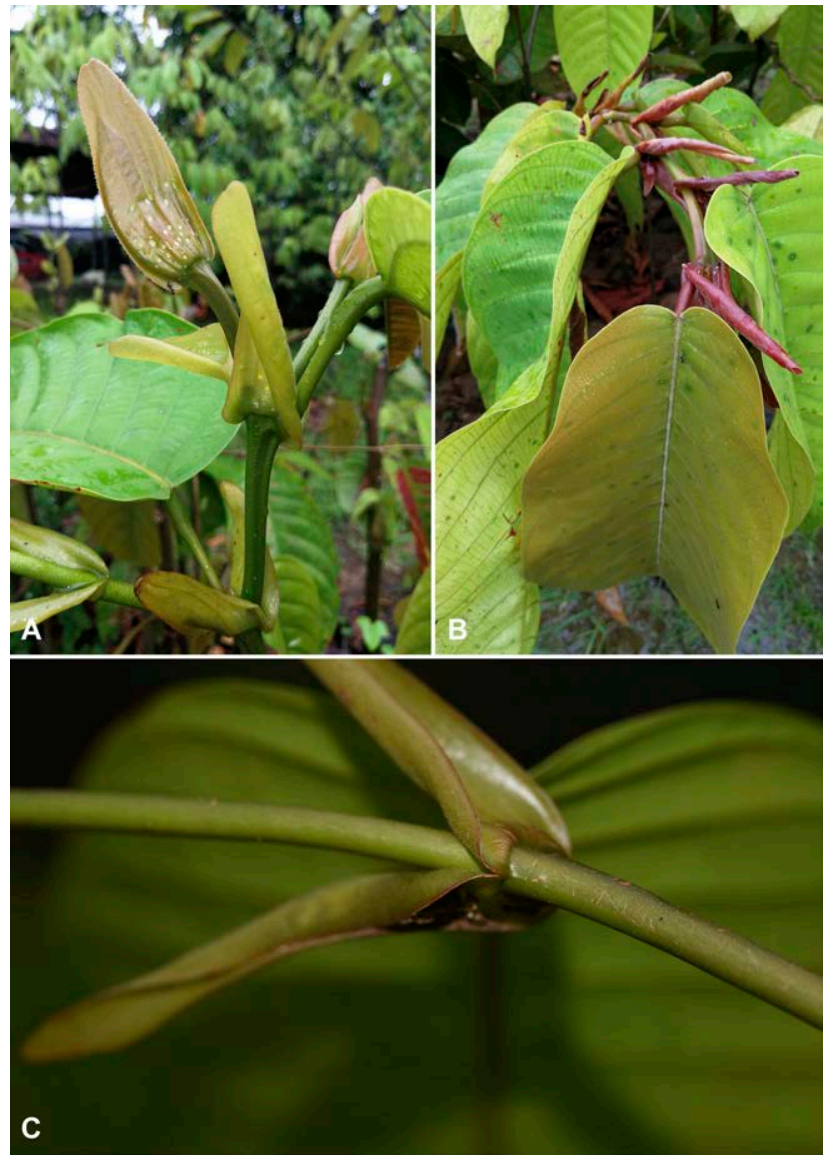

Figure 2. Shorea macrophylla (A) active shoot tip of sapling. Note the long revolute stipules and the pale elliptical extrafloral nectaries on the newest stipules. (B) shoot tip of the red stipule expression. The extrafloral nectaries are clearly visible on the leaf blades. (C) detail of the amplexicaul bases of a stipule pair.

at the geniculum, in marked contrast to the spiralled leaves of the erect stem which have long slender petiole.

West Borneo has had four dipterocarp masting events over past five years with the result that it has been possible to study several large populations of saplings and young trees (up to $5 \mathrm{~m}$ tall) of Shorea macrophylla. Observations revealed that almost every one of the several hundred plants we examined had Crematogaster ants associated with the active shoot tips, attracted to conspicuous extra floral nectaries on the exterior of the long stipules, and on the adaxial surface of the emerging and expanding leaf blades (Figure $3 \& 4$ ). Further examination of the typically revolute stipules revealed that they were often being used as brood chambers (Figure 5), with the loose edge of the tube packed with fragments of forest litter. On disturbance the ants hurriedly cleared the stipule of eggs (Figure 5). Although we did not see any active defence of the shoot tips by the ants 

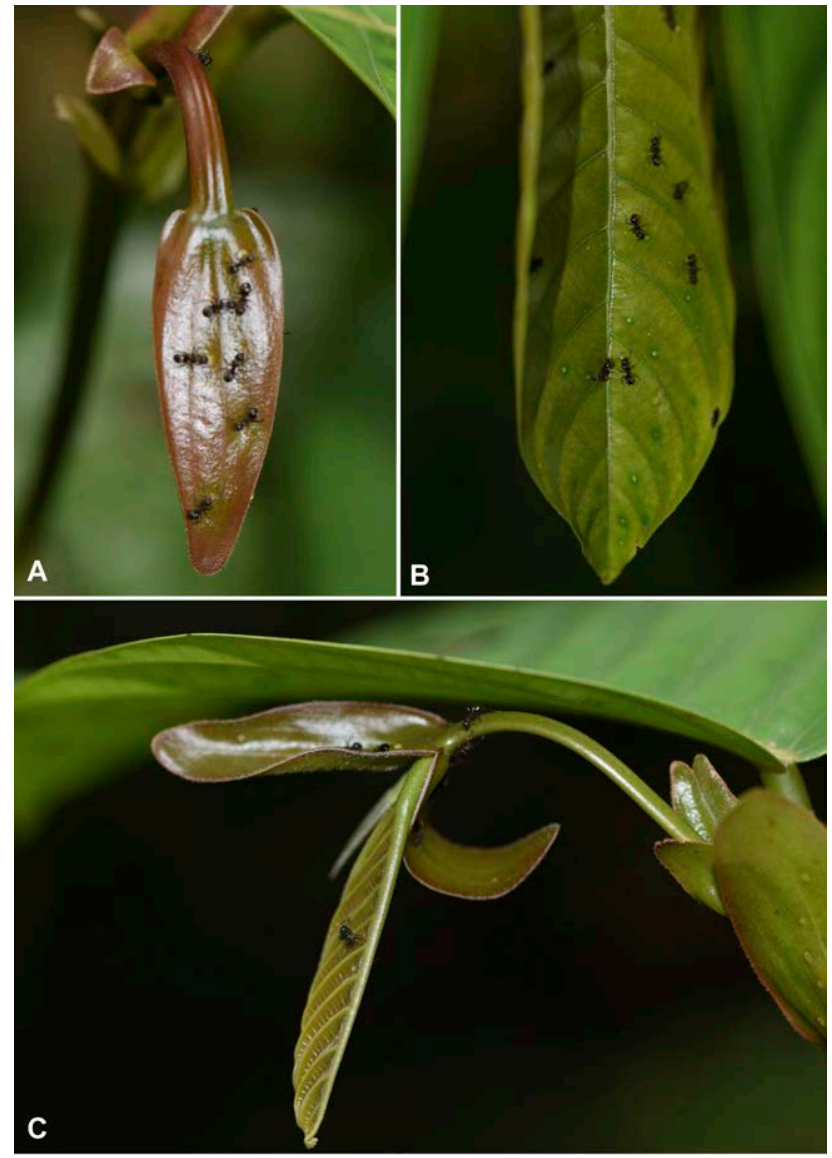

Figure 3. Shorea macrophylla (A) Crematogaster ants feeding on stipular extrafloral nectaries. (B) Crematogaster ants feeding on leaf blade extrafloral nectaries. (C) shoot tip with associated Crematogaster ants.

against herbivorous pests, it was notable that none of the plants with ant association showed any sign of caterpillar and chrysomelid beetle damage to the leaf blades, whereas the few plants encountered without ants had extensive damage (Figure 6).

Although the observations presented here are solely associated with saplings and for a single species, and in no way a statistically proven set of data, they are compelling evidence that ant associations exist in Dipterocarpaceae and that both parties appear to gain advantage - food and brood sites for the ants and rather clear evidence that leaf blade damage is negligible in plants with associated ants. Much more detailed studies are required for S. macrophylla in particular to determine if ant associations continue into the mature tree canopy, and if they do whether the same of ants are involved, or if a different species is recruited, or if the exposure of the saplings results in different ant species associations. It is also important that the study is extended to more

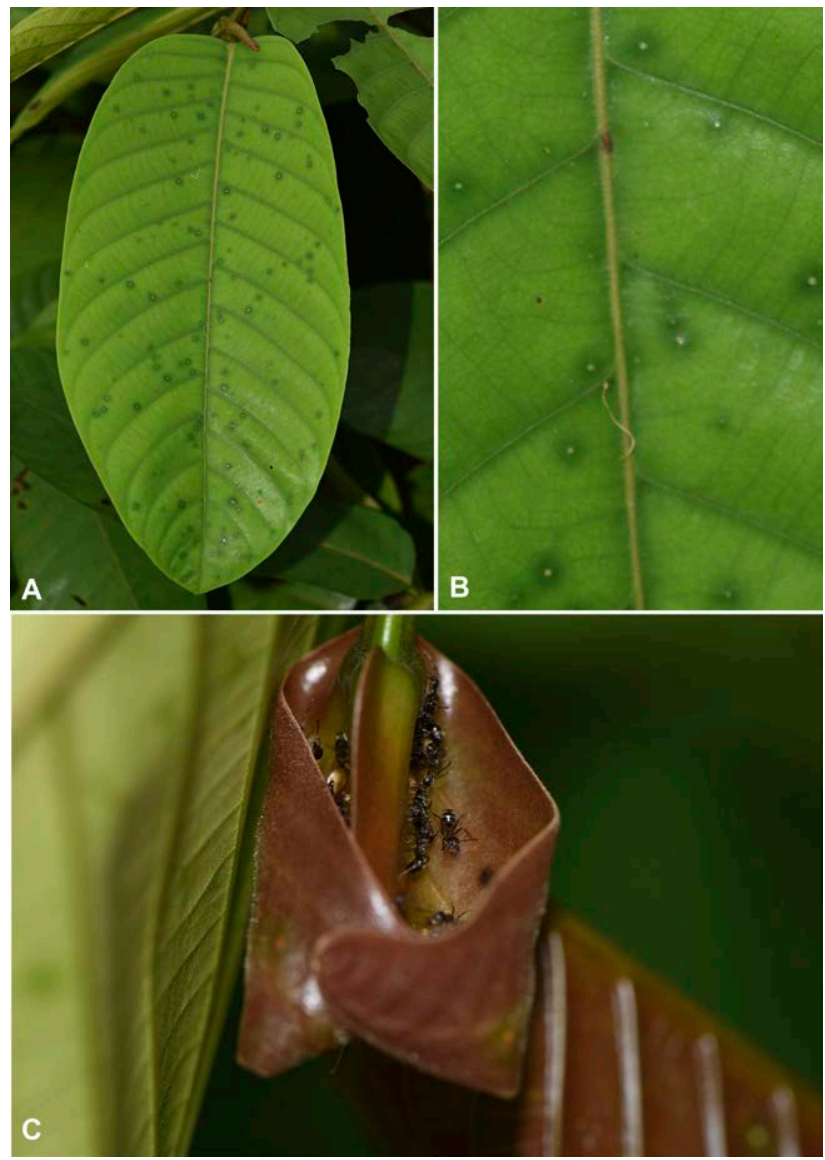

Figure 4. Shorea macrophylla (A) leaf blade showing extrafloral nectaries. (B) detail of leaf blade extrafloral nectaries. (C) shoot tip with associated Crematogaster ants.

species of Shorea on Borneo. As it stands, we have evidence that two further species of sect. Pachycarpae (Shorea splendida (de Vriese) P.S.Ashton and a species we are yet to be able to name) have ant associations, although seemingly no nesting.

\section{STIPULE CHARACTERS AND TAXONOMY}

Given the ecological importance of the species, the local community level economic significance of the fruits ('nuts') as a source of a high grade fat (see for example Blicher-Mathiesen 1994), and by no means least that Shorea macrophylla is one of the most readily recognizable species of dipterocarp on Borneo, there is an remarkable level of taxonomic and morphological muddle and misinformation in the primary literature (Ashton 1982, 2004). In particular there is confusion concerning diagnostic characteristics, notably the erroneous report of flattened stipules (Ashton 2004: 204), and the supposed presence 


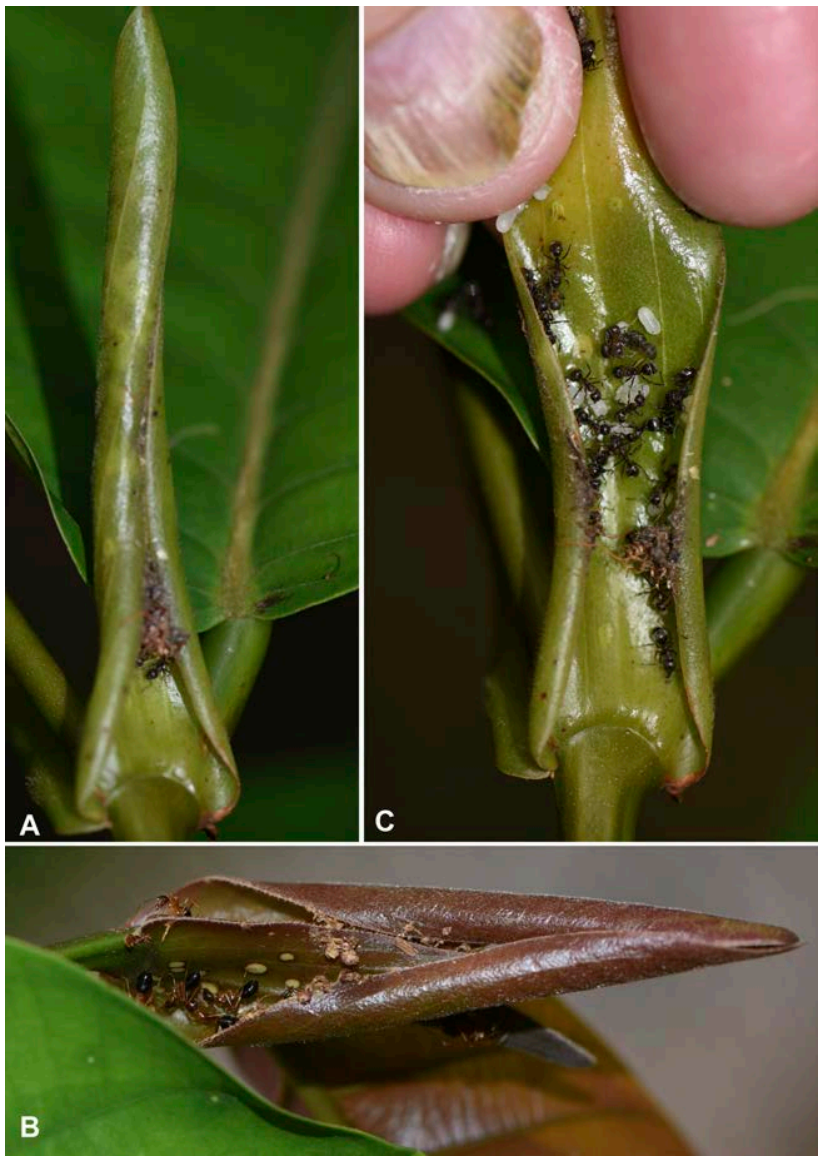

Figure 5. Shorea macrophylla (A) revolute stipule containing a Crematogaster ant brood chamber. Note the debris used to seal the open edges of the stipule. (B) the same stipule artificially opened with ants removing eggs. (C) another stipule brood chamber opened to show the (formerly external) extrafloral nectaries which are enclosed as the stipule margins recurves to fashion the tube.

of "persistently densely evenly pale brown pubesce(ense)" of "stipule..., petiole, leaf blade below, and midrib above". In reality the stipules of $S$. macrophylla are consistently revolute (Figure 1, $2 \& 5$ ), while with the exception of the stipules, which are externally sub-microscopically glandular-stellate-pubescent, all the above-mentioned parts are entirely glabrous (Figure 5).

Remarkably, the conspicuous extra floral nectaries on the stipules and leaf blades (Figure $1 \& 4$ ) are not mentioned at all in the primary taxonomic literature, although Maury-Lechon \& Curtet (1998: 11) state that "Extra-floral nectaries were recently found in many genera (Ashton, personal communication)", the presence of such structures in African Monotes A.DC. was reported by Verdcourt (1989), and Balgooy et al. (2015), Fiala and Saw (2003), and Moog et al. (2003) all make note of their presence.

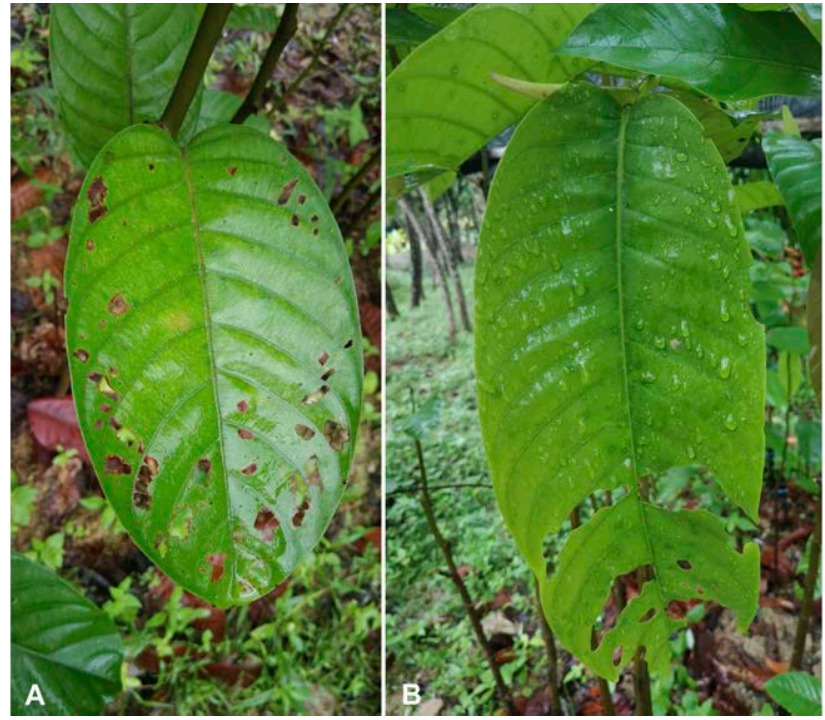

Figure 6. Shorea macrophylla (A) leaf blade showing typical chrysomelid beetle damage associated with saplings that have no ant association. (B) leaf blade showing typical caterpillar damage associated with saplings that have no ant association.

Given the above points, and that the sapling stages of most Shorea have never been adequately documented, and with that the descriptions of the often highly diagnostic stipules are often at best inadequate, it seems useful to provide a proper description here.

Shorea macrophylla (de Vriese) P.S.Ashton, Gard. Bull. Singapore 20(3): 278. 1963.

Stipules paired, tightly appressed in bud, soon divergent with the margins strongly revolute to fashion a tube, rather briefly persistent with the pair falling to leave a conspicuous scar by the time the associated shoot has increased in length by about five additional nodes; stipules equal, up to $5 \mathrm{~cm}$ long by $1.5 \mathrm{~cm}$ wide, rather narrowly lingulate, bases amplexicaul, briefly and narrowly auriculate, externally sub-microscopically glandular-pubescent, either dull rich red with scattered elliptical green extrafloral nectaries, or bright green with pale yellow nectaries, interior glabrous, somewhat waxy, concolorous with exterior, lacking extrafloral nectaries.

\section{SCOPE FOR FURTHER WORK}

Our observations are based on seedlings and saplings of a single species in detail, and two further species for which we have partial observations. Comprehensive 
studies of more species are highly desirable, especially in situations of high species diversity.

\section{ACKNOWLEDGEMENTS}

Fieldwork associated with this research was most recently under Sarawak Forestry Department Permission to Conduct Research on Biological Resources - Permit No. (67) JHS/NCCD/600-7/2/107/Jld.2 and Park Permit No WL33/2019. The collaboration and support of the Sarawak Forestry Department, the Forest Research Centre (Kuching), and the Sarawak Biodiversity Centre are gratefully acknowledged. The second author extends his thanks to Tan Sri Datuk Amar Leonard Linggi Anak Jugah and Malesiana Tropicals Sdn Bhd for continued support and encouragement.

\section{REFERENCES}

Ashton PS. 1963. Taxonomic notes on Bornean Dipterocarpaceae. Gardens' Bulletin Singapore 20(3): 229-284.

Ashton PS. 1982. Dipterocarpaceae. In: van Steenis CGGJ [ed.], Flora Malesiana, Series I, Spermatophyta 9(2): 237-552 \& 561-562. The Hague, Nijhoff,

Ashton PS. 2004. Dipterocarpaceae. In: E. Soepadmo, L.G. Saw \& RCK. Chung [eds], The Tree Flora of Sabah and Sarawak 5, 62-388 \& 485-486. Forest Research Institute Malaysia (FRIM), Sabah Forestry Department, Malaysia, Sarawak Forestry Department, Malaysia.

Balgooy MMJ van, Low YW, Wong KM. 2015. SpotCharacters for the Identification of Malesian Seed Plants, A Guide. Kota Kinabalu, Natural History Publications (Borneo).

Beccari O 1884-1886. Piante ospitatrici, ossia piante formicarie della Malesia e della Papuasia. Malesia (Genoa) vol. II, fasc. 1-2 (1884), fasc. 3 (1885), fasc. 2 (1886).

Blicher-Mathiesen U. 1994. Borneo illipe, a fat product from different Shorea spp. (Dipterocarpaceae). Economic Botany 48(3): 231-242.

Chan C S-Y, Cheng J, Loh JYQ, Tan E., Loo AHB, Tang JH 2012. Observations of ants and aphids in the rattan species Korthalsia echinometra Becc. and Korthalsia rostrata Blume. The Raffles Bulletin of Zoology 25: $133-139$.

Clausing G. 1997. Observations on ant-plant interactions in Pachycentria and other genera of the Dissochaeteae (Melastomataceae) in Sabah and Sarawak. Flora 193(4): 361-368
Fiala B, Maschwitz U, Tho YP 1991. The association between Macaranga and ants in South East Asia, pp 263-270. In: C.Huxley \& DF Cutler [eds], Interactions between ants and plants. Oxford University Press, Oxford,

Fiala B, Saw LG. 2003. Ant fauna of the lower vegetation stratum in Pasoh Forest Reserve with special reference to the diversity of plants with extrafloral nectaries and associated ants. In: T. Okuda, N. Manokaran, Y. Matsumoto, K. Niiyama, S.C. Thomas \& P.S. Ashton (eds.), Pasoh, Ecology of a Lowland Rain Forest in Southeast Asia. Tokyo, Springer. Pp. 437-458.

Heckenhauer J, Samuel R, Ashton PS, Turner B, Barfuss MHJ, Jang T-S, Temsch EM,

McCann J, Kamariah AS, Achala AM, Attanayake S, Chase MW. 2017. Phylogenetic analyses of plastid DNA suggest a different interpretation of morphological evolution than those used as the basis for previous classifications of Dipterocarpaceae (Malvales). Botanical Journal of the Linnean Society 185: 1-26.

Heckenhauer J, Samuel R, Ashton PS, Kamariah AS, Paun O, 2018. Phylogenomics resolves evolutionary relationships and provides insights into floral evolution in the tribe Shoreeae (Dipterocarpaceae). Molecular Phylogenetics and Evolution 127: 1-13.

Heckenhauer J, Paun O, Chase MW, Ashton PS, Kamariah AS \& Samuel R. 2019. Molecular phylogenomics of the tribe Shoreeae (Dipterocarpaceae) using whole plastid genomes. Annals of Botany 123: 857-865.

Huxley CR. 1978. The ant-plants Myrmecodia and Hydnophytum (Rubiaceae), and the relationships between their morphology, ant occupants, physiology and ecology. New Phytologist 80(1): 231-268.

Jebb MHP \& Huxley CR. 2019. The tuberous epiphytes of the Rubiaceae 7: a revision of the genus Hydnophytum. Blumea 64: 23-91.

Kleijn D \& van Donkelaar R. 2001. Notes on the taxonomy and ecology of the genus Hoya (Asclepiadaceae) in Central Sulawesi. Blumea 46: 457-483.

Maury, G. 1978. Diptérocarpacées: du fruit à la plantule. Thèse de doctorat deetat, Université Paul Sabatier, Toulouse 3 vols., IA: 243p., IB: 432p., II: 344p.

Maury M 1979. Intérêt systématique et phylogénique des caractères juvéniles (germination, embryon mûr, plantules) chez les Diptérocarpacées. Bulletin de la Société Botanique de France. Actualités Botaniques 126(3): 13-21.

Maury-Lechon G. 1979a. Conséquences taxonomiques de létude des caractères des fruits/germinations, embryons et plantules des Diptérocarpacées, pp. 81-106. In: G Maury-Lechon [ed.], Dipterocarpaceae: taxonomie-phylogénie-ecologie. Paris: Memoires du Muse- 
um National d'Histoire Naturelle, serie B, Botanique, Editions du Museum.

Maury-Lechon G. 1979b. Interprétation phylogénique des caractères des pollens, fruits germinations et plantules des Diptérocarpacées, pp. 139-144. In: G Maury-Lechon [ed.], Dipterocarpaceae: taxonomie-phylogénie-ecologie. Paris: Memoires du Museum National d'Histoire Naturelle, serie B, Botanique, Editions du Museum.

Maury-Lechon G, Curtet L. 1998. Biogeography and evolutionary systematics of family Dipterocarpaceae, pp. 5-44. In: S Appanah \& JM Turnbull [eds], A review of dipterocarps, taxonomy, ecology and silviculture. Bogor: Center for Forest Research Institute.

Miler K, Yahya BE, Czarnoleski M. 2016. Reduced damage and epiphyll cover of leaves of Korthalsia rattans that host Camponotus ants in the rain forest of Malaysian Borneo. Journal of Tropical Ecology 32(4): 330-334.

Moog J, Fiala B, Werner M, Weissflog A, Saw LG, Maschwitz U. 2003. Ant-plant diversity in Peninsular Malaysia with special reference to the Pasoh Forest Reserve. In: T. Okuda, N. Manokaran, Y. Matsumoto, K. Niiyama, S.C. Thomas \& P.S. Ashton (eds.), Pasoh, Ecology of a Lowland Rain Forest in Southeast Asia. Tokyo, Springer. Pp. 459-494.

Peeters C, Wiwatwitaya D. 2014. Philidris ants living in Dischidia epiphytes from Thailand. Asian Myrmecology 6: 49-61.

Razafimandimbison SG, Moog J, Lantz H, Maschwitz U, Bremer B. 2005. Re-assessment of monophyly, evolution of myrmecophytism, and rapid radiation of Neonauclea s.s. (Rubiaceae). Molecular Phylogenetics and Evolution 34: 334-354.

Van Leeuwen Docters WML, 1913. Beitraege zur Kenntnis der Lebensweise einiger Dischidia- Arten. Annales du Jardin botanique de Buitenzorg. 27: 65-91.

Van Leeuwen Docters WML, 1929a. Kurze Mitteilungen über Ameisenepiphyten aus Java. Berichte der Deutschen Botanischen Gesellschaft 47: 90-97.

Van Leeuwen Docters WML, 1929b. Mierenepiphyten I. De Tropische Natuur 18: 57-64.

Van Leeuwen Docters WML, 1929c. Mierenepiphyten II. De Tropische Natuur 18: 131-139.

Verdcourt B. 1989. Flora of Tropical East Africa. Dipterocarpaceae. Balkeman A.A., Rotterdam. 11pp.

Weissflog A, Kaufmann E, Maschwitz U. 2017. Ant gardens of Camponotus (Myrmotarsus) irritabilis (Hymenoptera: Formicidae: Formicinae) and Hoya elliptica (Apocynaceae) in Southeast Asia. Asian Myrmecology 9: e009001: 1-16. 